\title{
Research progress of fishpass in China
}

\author{
Hongxia Xiong \\ Tianjin Research Institute for Water Transport Engineering, Key Laboratory of Environmental \\ Protection in Water transport Engineering, Ministry of Transport, Tianjin 300456, China \\ E-mail: xiongxiongbao@126.com
}

\begin{abstract}
Keywords: fishpass; history; current situation; progress
Abstract. Fishpass, an effective way providing passage for fish swimming by connecting upstream and downstream flow, has been used as an important measure of fish protection on hydropower and navigation power junction project construction. However, due to the lack of awareness, funding, operation management and other factors, the role it plays and the effects are difficult to be sure. According to the status quo of fishpass operation management system at home and abroad, the history and main structure types of the fishpass are detailed introduced. Finally it is proposed that the research and design of the fishpass should be enhanced to a new step at present and in the future.
\end{abstract}

\section{Introduction}

In order to improve the effective use of the water resource and the function of preventing flood, improve water environment and shipping ets, many dams were constructed on large and small rivers (e.g., Xiaonanhai Dam on the Yangtze River, upstream of the Three Gorges Reservoir, and a sluice gate between the Yangtze River and Poyang Lake). By 2008, there were 5,191 dams, $30 \mathrm{~m}$ or more in height, that had been constructed in China [1]. The connection of river and the instream ecological water requirement are impacted by dam and navigation power junction construction, which produced sudden, enormous changes in the environment for anadromous fish. Many documents had reported the fragmentation effects from dams on migratory fishes [2-4].

As a special releasing structure, fishpass can help the fish species migrate through the dam or gate successfully. It is essential to maintain the river continuum and intercommunion between different fish species. This article provides a historical review of fish passage in China and the design issues involving in the fishpass are analyzed. Finally it is proposed that the research and design of the fishpass should be enhanced to a new step at present and in the future.

\section{Historical review of fish passage in China}

\section{Initial development period}

The history of experience with upstream or downstream fishpass was short compared to many Western countries. The fishpass was first mentioned when a series of studies associated with developing the Qililong Hydropower Station, Fuchun River, Heilongjiang Province were carried out. The first fishpass built in China was the Xinkailiu Fishpass, which was built in 1960 (CFRTCDAP, Anhui Province 1972 [5]. During the 1960s and 1970s, there were more than 40 fishpass were built in China, which mainly distributed in Jiangsu, Zhejiang, Shanghai, Anhui, Guangdong, Hunan, and a few other provinces. But there were no fishpass design criteria in China at that time, so these fishpasses were designed according to the experience from the western world. Fishpass provided passage for fish swimming by connecting upstream and downstream flow and play a role in protecting the river ecosystem. However, almost all fishpass were nonfunctional within a few years after construction, mainly due to the poor process of fishway design and construction as well as inadequate maintenance, lack of funds, and unclear regulations as to the parties responsible for fishpass management [6].

In order to improve the fishpass effectiveness, both the federal and provincial government bodies (Ministry of Water Conservancy and Hydroelectricity and Ministry of Aquatic Products) released the 
issuance of the Notice on Protection of Proliferation Aquatic Resources on Hydro Construction and Management. The Ministry of Water Resource and Hydroelectricity and the Ministry of Agriculture and Forestry held the Conference on Experience of fishpass Facilities in 1974 [7]. This conference promoted the fishpass development and the protection and proliferation of aquatic resources in water conservancy work.

\section{Stagnation period}

From 1980s to 90s, the fishpass development in China entered a period of stasis. The stagnation of fishpass development is mainly affected by the controversy over the fish engineering measures of the Gezhouba Water Control Project. Some scientist proposed that Chinese Suckers did not need to migrate upstream of the dam and construction of an upstream fishpass could not solve the problems for Chinese Sturgeon and Chinese Paddlefish because it would not provide both upstream and downstream passage [8]. Thus, artificial spawning and stocking of early life stages of the target species blocked by the Gezhouba Dam were adopted as mitigation for fish passage. However, some research data indicated that the downstream of the three locks was the most fish accumulation of the place, that indicated that the fish still instinctively through the dam upstream [9], which showed that simply setting proliferation of station could not solve the problem. The proliferation of station only alleviated the problem of the Chinese sturgeon swimming to upstream, but did not result in successful spawning and recruitment of target species, for example, Chinese Sturgeon and Chinese Sucker, so it also could not maintain river connectivity and ecological environment. Fortunately, more and more people have been aware of the ecological problems caused by dams and navigation power junctions, which provided a conservation foundation for fishpass development in China.

\section{Secondary development period}

Water resources utilization is more and more urgent with the rapid development of society and economy. The hydropower engineering and navigation power junctions were important for economic development. The scale and quantity of hydropower engineering became more and more large recently years. Due to the construction of water conservancy and hydropower project, the original waters and hydrological situation in river has been a prodigious change, it has brought about a series of eco-environmental problems affecting the sustainable development of river ecosystem. So fishpass construction was mentioned again. In order to protect river ecosystem, some laws required to build fishpass at new dams [6-7]. the People's Republic of China on Water (2002) encouraged the development and utilization of streams but also required the builder of any dam to build and pay for facilities for fish passage, vessel passage, and transport of commercial logs (harvested trees) when the rivers provided these functions before impoundment. Law of the People's Republic of China on Fishery, which states that if construction of a sluice gate or dam has deleterious effects on the migration of fish, shrimp, or crab, the builder shall adopt fishpass facilities or other remedial measures (Song et al. 2008).

Since 2000, 25 fishpass have been built (Table 1) [10]. The types mainly include pool-weir, vertical-slot, pool-orifice, open-channel, natural bypass. Eighty-three percent fishpass is vertical-slot ladder, mainly because vertical-slot ladders provide passage at all water depths and can be built at low cost. The seminatural bypass is the second most popular fishpass design [11].

Pool-type: The pool includes the weir-orifice fishpass and the vertical slot fishpass. In weir-orifice fishpass, fish typically move upstream through the orifice at the floor of the fishpass, not over the weir. The pool type fishpass was first developed in the 1930s for Bonneville Dam on the Cohmbia River.

Baffled Chute: Baffled chutes include the Denil fishpass and the Alas ka Steeppass fishpass. These types of fishpass are useful where the elevation gradient is a constraint.

Nature like: Nature like fishpass attempt to provide a "natural" route with as few man-made structures as possible. This method has been attempted in many locations, including the U.S. Midwest, Canada, South America, Europe and elsewhere, and typically applies to weaker swimming fish.

The passing fishes, fishpass structure and arrangement as well as the main designing parameters of a fishpass are analyzed and discussed. But the design of the lack of scientific research for the target 
fish species' habits, most of the effectiveness of fishpass is nonfunctional within a few years after construction.

\section{The future of fishpass development in China}

Even though fish scientists and hydraulic engineers are enthusiastic to develop fishpass, progress is limited mainly because of (1) the lack of an accepted and enforced process to plan, design and evaluate fishpass; (2) the lack of knowledge on migratory fish life history movement, behavior and swimming ability; and (3) the failure of fish biologists and engineers to work together as a fishpass team. Future development should focus on the following: educating agency staff, fish biologist, and the public on the importance of river connectivity and migratory fish conservation using fishpasses; improving regulations; and setting national standards that require scientific evaluation of all fishpass. We also suggest consideration of the following: a reward system, basic fish biological research, national fishpass research and development centers, and collaboration by Chinese engineers and biologists with foreign fishpass expertise.

(1) Designated the management units of fishpass by laws

The fishpass construction and management involve the water conservancy, fishery, electricity, environmental protection, investor and the public benefit, so a successful fishpass need multiple departments to work together. At present, our law has not defined explicity to management of fishpass.

(2) Setting the standard specification for fishpass construction

Fish passes have been developed mainly in North America and Europe for a very limited number of target species present in these countries, mainly salmonids and clupeids. The construction of fishpass started late, yet appeared stoppage during the period, until recent years fisspass again all around dam, hydropower and navigation power junctions project construction. In the absence of good knowledge on the fishpass construction, the related parameters and management requirements about the design, construction and operation of the basic data, the protection object, design principle, water level, body position, migratory fish season, flow rate, inlet position and outlet position, pond design and other technical are lack of universal criteria, which affects the validity and generalization possibility of fishpass design.

(3) Efficiency monitoring and assessment of the fishpass

Due to the lack of awareness, funding, operation management and other factors, there is no long-term monitoring of the operation of the fishpass. The effectiveness monitoring step is the primary method for determining whether the targeted migrating fish will respond as desired to the fishpass. The philosophy is to use the fish to indicate the level of success, and apply the lessons learned from observing their behavior to improve the current and future fishpass through adaptive management.

\section{Conclusion}

Fishpass has garnered the attention of worldwide researchers for hundreds of years. However, China developed fish passage only since 1960s and almost vacant research and application since 1980s, until 2000s. Fishpass research and application became popular in China. There is a large gap between the willing to protect fish and actual fish passage efficiency, due to many reasons including the understanding of fish protection from stakeholder, limited knowledge on fish biology, concept update of fish passage design, and management. Even though, researchers and engineers are enthusiastic to develop fish passage. Future development should mainly focus on (1) Reinforce the acknowledgement of ecological protection. (2) Clarify parties responsible for fish passage construction, operation and management in laws. (3) Cultivate professional experts. (4) Develop global intelligence consultation. (5) Strengthen fundamental research related to fish biology and hydraulics. (6) Enact the standards for fishpass construction in China. (7) Optimize operation management on fishpass. (8) Establish the fishpass effectiveness assessment mechanism, and connect assessment to the project's benefit and the builder's credit. 


\section{Acknowledgements}

This work was financially supported by the Science and Technology Development Fund Program of Tianjin Research Institute for Water Transport Engineering, M.O.T. (KJFZJJ150101).

\section{Literature References}

[1] J. Jia, Y. Yuan, C. Zheng, and Z. Ma. 2009. 1st International Symposium on Rockfill Dam, Chengdu, China. (2008).

[2] A. García, K. Jorde, E. Habit, D. Caamano, and O. Parra. River Research and Applications Vol. 27(3) (2011), p.312-327.

[3] J.S. Tiemann, D.P. Gillette, M.L. Wildhaber, and D.R. Edds. Transactions of the American Fisheries Society Vol. 133(3) (2004), p. 705-717.

[4] Y. Zhong, and G. Power. Regulated Rivers: Research and Management Vol. 12 (1996), p. 81-98.

[5] Y. Wang. In Proceedings of the International Symposium on Fishways. Gifu, Japan. (1990).

[6] K.Q. Chen, Z.N. Chang, X.H. Cao, and H.F. Ge. Journal of Hydraulic Engineering Vol. 43(2) (2012), p. 182-197.

[7] D.J. Song, H. Jang, C.T. Guan, and Q.S. Chen. Marine Fisheries Research Vol. 1 (2008), p. 92-97.

[8] B. Yi. Reservoir Fishery Vol. 1 (1982), p. 4-9.

[9] H.B. Liu. Journal of Anhuii Agricultural Sciences Vol. 14 (2010), p. 7566-7567.

[10] X.T. Shi, B. Kynard, D.F. Liu, et al. Fisheries Vol. 40 (4) (2015), p. 161-169.

[11] X.H. Cao, M Chen., and W. Lv. Special issue for maintaining of river connectivity in Symposium for Ecology Conservation of Water Conservancy and Hydropower Projects, Nanning, China, (2013). 
Table 1 Characteristics of fishpass in China (2000-2013)

\begin{tabular}{|c|c|c|c|c|c|c|c|c|c|}
\hline & Fishpass name & Province & River basin & Target species & $\begin{array}{l}\text { Height } \\
(\mathrm{m})\end{array}$ & Fishpass type & $\begin{array}{l}\text { Length } \\
(\mathrm{m})\end{array}$ & $\begin{array}{l}\text { Velocity } \\
(\mathrm{m} / \mathrm{s})\end{array}$ & $\begin{array}{l}\text { Discharge } \\
\left(\mathrm{m}^{3} / \mathrm{s}\right)\end{array}$ \\
\hline 1 & Sanwan HJP & Liaoning & Ai River & Trachidermus fasciatus & 28.02 & Vertical-slot & 799.2 & $0.5 \sim 0.8$ & 0.41 \\
\hline 2 & Yuliang HNP & Guangxi & You River & $\begin{array}{l}\text { Spinibarbus caldwelli, Spualiobarbus } \\
\text { curriculus, Parabramis pekinensis, } \\
\text { Ctenopharyngodon idella, Hypophthalmichthys } \\
\text { molitrix, Hypophthalmichthys nobilis, } \\
\text { Mylopharyngodon piceus }\end{array}$ & 11.8 & Vertical-sl ot & 601.92 & $0.8 \sim 1.1$ & 1.03 \\
\hline 3 & $\begin{array}{l}\text { Hydro-Compl } \\
\text { ex } \\
\text { on Xiang } \\
\text { River }\end{array}$ & Hunan & Xiang River & $\begin{array}{l}\text { Ctenopharyngodon idella, Hypophthalmichthys } \\
\text { molitrix, Hypophthalmichthys nobilis, } \\
\text { Mylopharyngodon piceus }\end{array}$ & 39.7 & Vertical-sl ot & 930.0 & $0.8 \sim 1.0$ & 1.8 \\
\hline 4 & $\begin{array}{l}\text { Second } \\
\text { Diversion } \\
\text { HJP in Kaidu } \\
\text { River }\end{array}$ & Xinjiang & Kaidu River & $\begin{array}{l}\text { Gymnodiptychys dybowskii, Schizothorax } \\
\text { biddulphi }\end{array}$ & & Vertical-sl ot & 123.0 & $0.6 \sim 1.0$ & 0.74 \\
\hline 5 & Xia River HJP & Jiangxi & Gan River & $\begin{array}{l}\text { Ctenopharyngodon idella, Hypophthalmichtlys } \\
\text { molitrix, Hypophthalmichthys nobilis, } \\
\text { Mylopharyngodon piceus andlocal fish }\end{array}$ & 28.7 & Vertical-sl ot & 905.0 & $0.7 \sim 1.1$ & 2.5 \\
\hline 6 & $\begin{array}{l}\text { Yindajihuang } \\
\text { Project }\end{array}$ & Qinghai & $\begin{array}{l}\text { Datong } \\
\text { River }\end{array}$ & $\begin{array}{l}\text { Gymnodiptychus pachycheilus, Gymnocypris } \\
\text { eckloni, Schizopygopsis pylzovi }\end{array}$ & 11.2 & Vertical-sl ot & 374.4 & $0.8 \sim 1.2$ & 1.35 \\
\hline 7 & Yilan HNP & Heilongiiang & $\begin{array}{l}\text { Songhua } \\
\text { River }\end{array}$ & $\begin{array}{l}\text { Ctenopharyngodon idella, Hypophthalmichthys } \\
\text { molitrix, Hypophthalmichthys nobilis }\end{array}$ & 6 & Natural bypass & 1010.4 & $0.8 \sim 1.2$ & 2.0 \\
\hline 8 & Angu HPS & Sichuan & Dadu River & $\begin{array}{l}\text { Pelteobagrus vachelli, Pseudogyrinocheilus } \\
\text { procheilus, Pseudobagrus truncates, } \\
\text { Parasilurus asotus, Megagobio ventralis, } \\
\text { Leptobotia elongate, Mystus macropterus, } \\
\text { Pelteobagrus fuvidraco }\end{array}$ & 28.7 & Natural bypass & 711.0 & $1.0 \sim 1.2$ & 5.0 \\
\hline 9 & Shiquan River & Tibet & Indus River & $\begin{array}{l}\text { Schizothorax plagiostomus, Ptychobarbus } \\
\text { conirostris }\end{array}$ & 32 & Vertical-sl ot & 735.0 & 1.0 & 2.7 \\
\hline 10 & $\begin{array}{l}\text { Shihutang } \\
\text { HNP }\end{array}$ & Jiangxi & $\begin{array}{l}\text { the Yangtse } \\
\text { River }\end{array}$ & $\begin{array}{l}\text { Ctenopharyngodon idella, Hypophthalmichthys } \\
\text { molitrix, Hypophthalmichthys nobilis, Alosa } \\
\text { reevesii, Mylopharyngodon piceus }\end{array}$ & 9.0 & Vertical-sl ot & 713.0 & $0.5 \sim 1.2$ & \\
\hline 11 & $\begin{array}{l}\text { Changzhou } \\
\text { Hydraulic } \\
\text { Complex }\end{array}$ & Guangxi & Xi River & $\begin{array}{l}\text { Acipenser sinensis, Alosa reevesii, Coilia grayi, } \\
\text { Anguilla japonica, Anguilla marmorata, } \\
\text { Leucosoma chinensis }\end{array}$ & 49.3 & Vertical-sl ot & 1423.4 & 0.8 & 70 \\
\hline 12 & $\begin{array}{l}\text { Laolongkou } \\
\text { HJP }\end{array}$ & Jilin & $\begin{array}{l}\text { Huichun } \\
\text { River }\end{array}$ & $\begin{array}{l}\text { Oncorhynchus masou, Oncorhynchus keta, } \\
\text { Lampetra japonica }\end{array}$ & 42.4 & Vertical-sl ot & 281.6 & $\begin{array}{l}0.45 \sim 1.6 \\
5\end{array}$ & \\
\hline 13 & $\begin{array}{l}\text { Caoe River } \\
\text { Sluice }\end{array}$ & Zhejiang & $\begin{array}{l}\text { Qiantang } \\
\text { River }\end{array}$ & Anguilla japonica & 13.4 & Open-channel & 507.2 & $0.15 \sim 0.5$ & \\
\hline 14 & $\begin{array}{l}\text { Cuijiaying } \\
\text { HNP }\end{array}$ & Hubei & Han River & $\begin{array}{l}\text { Pelteobagrus fulvidraco, Rhinogobio typus, } \\
\text { Parabramis pekinensis, Hypophthalmichthys } \\
\text { molitrix, Hypophthalmichthys nobilis, } \\
\text { Ctenopharyngodon idella, Mylopharyngodon } \\
\text { piceus }\end{array}$ & 13 & Vertical-sl ot & & $0.5 \sim 0.8$ & $1.8 \sim 2.8$ \\
\hline 15 & Xinglong HJP & Hubei & Han River & $\begin{array}{l}\text { Anguilla japonica, Coilia macrognathos, } \\
\text { Ctenopharyngodon idella, Hypophthalmichthys } \\
\text { molitrix, Hypophthalmichthys nobilis, } \\
\text { Mylopharyngodon piceus }\end{array}$ & 19.2 & Vertical-slot & 105.5 & 1 & 0.65 \\
\hline 16 & Xiniu HNP & Guangdong & Bei River & $\begin{array}{l}\text { Gobio gobio, Cyprinus carpio, Zacco platypus, } \\
\text { Opsariichthys bidens, Mystus guttatus }\end{array}$ & 19.5 & Vertical-sl ot & & 1.4 & \\
\hline 17 & Laokou HJP & Guangxi & Yu River & Anguilla japonica, Leucosoma chinensis & 42 & Vertical-slot & 708.87 & 0.8 & 1.08 \\
\hline 18 & $\begin{array}{l}\text { Zoumatang } \\
\text { Project }\end{array}$ & Jiangsu & Taihu Lake & $\begin{array}{l}\text { Lampetra japonica, Hypophthalmichthys } \\
\text { molitrix, Hypophthalmichthys nobilis, } \\
\text { Parabramis pekinensis, Eriocheir sinensis }\end{array}$ & 9.4 & Vertical-sl ot & 60.0 & & \\
\hline 19 & Lidi HPS & Yunnan & $\begin{array}{l}\text { Lancangiian } \\
\text { g River }\end{array}$ & $\begin{array}{l}\text { Schizothorax griseus, Schizothorax } \\
\text { lantsangensis, Schizothorax lissolabiatus }\end{array}$ & 75 & Vertical-sl ot & 3000.0 & 1.1 & 0.63 \\
\hline 20 & $\begin{array}{l}\text { Second HPS } \\
\text { of } \\
\text { Shaping Dam }\end{array}$ & Sichuan & Dadu River & $\begin{array}{l}\text { Schizothorax davidi, Euchiloglanis davidi, } \\
\text { Onychostoma dachemsis, Beaufortia liui }\end{array}$ & 62 & Vertical-sl ot & 597.0 & 1.2 & 0.5 \\
\hline 21 & $\begin{array}{l}\text { First HPS of } \\
\text { Zhentou Dam }\end{array}$ & Sichuan & Dadu River & $\begin{array}{l}\text { Schizothorax davidi, Euchiloglanis davidi, } \\
\text { Onychostoma daduemsis, Beaufortia liui }\end{array}$ & 56 & Vertical-sl ot & 1300.0 & 1.2 & 1.08 \\
\hline 22 & Yongshui Dam & Jilin & $\begin{array}{l}\text { Songhua } \\
\text { River }\end{array}$ & $\begin{array}{l}\text { Ctenopharyngodon idella, Hypophthalmichtlys } \\
\text { molitrix, Hypophthalmichthys nobilis, } \\
\text { Mylopharyngodon piceus }\end{array}$ & 3 & Vertical-sl ot & 169.2 & $0.6 \sim 0.8$ & \\
\hline 23 & Fengman HPS & Jilin & $\begin{array}{l}\text { Songhua } \\
\text { River }\end{array}$ & $\begin{array}{l}\text { Lampetra japonica, Ctenopharyngodon idella, } \\
\text { Hypophthalmichthys molitrix, } \\
\text { Mylopharyngodon piceus }\end{array}$ & 94.5 & Vertical-sl ot & 1074.0 & 0.8 & 1.37 \\
\hline 24 & Xinji HPS & Hubei & Han River & $\begin{array}{l}\text { Anguilla japonica, Scaphesthes macrolepis, } \\
\text { Saurogobio gracilicaudatus, Ctenopharyngodon } \\
\text { idella, Hypophthalmichthys molitrix, } \\
\text { Hypophthalmichthys nobilis, Mylopharyngodon } \\
\text { piceus, Coreius heterodon, Elopichthys bambusa }\end{array}$ & 23.28 & & 812.2 & 1.0 & $0.5 \sim 0.6$ \\
\hline 25 & Duobu HPS & Tibet & $\begin{array}{l}\text { Yarlung } \\
\text { Zangbo } \\
\text { River }\end{array}$ & $\begin{array}{l}\text { Schizothorax oconnori, Schizothorax } \\
\text { macropogon, Schizothorax waltoni, } \\
\text { Oxygymnocypris stewarti }\end{array}$ & 27 & & 1407.6 & $0.9 \sim 1.1$ & \\
\hline
\end{tabular}

*Data were from published reference. Blank means information unavailable 